UDC 532.528

\title{
SHAPES OF STEADY SLENDER AXISYMMETRIC VENTILATED CAVITIES IN PONDERABLE LIQUID
}

\author{
I. G. Nesteruk ${ }^{1 \dagger}$, B. D. Shepetyuk ${ }^{2 \ddagger}$ \\ ${ }^{1}$ Institute of Hydromechanics of NAS of Ukraine \\ Zhelyabov Str., 8/4, 03057, Kyiv, Ukraine \\ †E-mail: inesteruk@yahoo.com \\ ${ }^{2}$ Yuriy Fedkovych Chernivtsi National Univesity, Chernivtsi \\ vul. Kotsyubynskyi Str., 2, 58012, Chernivtsi, Ukraine \\ ${ }^{\ddagger}$ E-mail: shepetyukb@gmail.com
}

\begin{abstract}
Received 17.12.2016
The shapes of the slender steady axisymmetric ventilated cavities are calculated for up- and downward directions of water flow at different values of the Froude number and radii of the cylindrical hulls located inside the cavity. The ventilation is shown to increase the dimensions of the cavities produced after the conical cavitator and to decrease the length of base cavities. If the direction of water flow at infinity is opposite to that of the gravity, the injection rate cannot exceed some critical value for conical cavitators and cannot be lower than some critical value for base cavities.
\end{abstract}

KEY WORDS: supercavitation, ventilated cavities, slender body theory

\section{INTRODUCTION}

The drag of the high-speed underwater vehicles can be reduced by decreasing the area wetted with water, i.e., by the use of supercavitation [1-3]. To obtain small cavitation numbers at small velocities or at large depths, a gas ventilation inside the cavity is used (see, e.g., [4]). The ventilation is also very important in experiments, since the velocities in water tunnels are usually much smaller than in the case of real vehicles. Limited velocities of water tunnels increase the influence of gravity on the cavity shape and dimensions.

Theoretical and numerical investigations of ventilated cavities are very limited. Even in the case when the effects of the gas flow inside the cavity and gravity are negligible, there is no complete theory for the cavity shape as a function of the gas supply rate, cavitation number and the shape of the body located inside the cavity. If an injected gas flows in a narrow channel between the cavity surface and the vehicle hull, the pressure on the cavity surface is no longer constant and changes the cavity shape in comparison with the case of vapor cavitation. This complicated phenomenon was investigated numerically with the use of viscous fluid equations [5]. The ideal fluid approach and the slender body theory allow one to obtain simple equations for the shape of axisymmetric ventilated supercavity provided the 
gas flow between the cavity surface and the body of revolution is one-dimensional inviscid and incompressible. Some interesting results were obtained in [6-8] for a steady flow of liquid without gravity effects.

In [9] the results of these papers are generalized for unsteady vertical flows in the gravity field. In particular, the first approximation equation for the radius $R(x)$ of steady axisymmetric ventilated cavity was proposed

$$
\frac{d^{2} R^{2}}{d x^{2}}=\frac{\sigma_{0}}{\ln \epsilon}+\frac{2 k x}{\operatorname{Fr}^{2} \ln \epsilon}+\Delta\left[a-\frac{1}{\left(R^{2}-R_{b}^{2}\right)^{2}}\right],
$$

where all lengths are dimensionless (refered to the cavity radius at its origin $R_{0}$ ), $k=1$ corresponds to the case, when the directions of the water flow at infinity and the gravitational acceleration coincide; $k=-1$ corresponds to the case, when the directions of these vectors are opposite (in order to have an axisymmetric cavity, the direction of the gravity force is limited by these two cases).

The constant parameters $\sigma_{0}, \mathrm{Fr}, \Delta$ and $a$ are given by formulas:

$$
\begin{gathered}
\sigma_{0}=\frac{2\left(p_{\infty}-p_{v}-p_{0}\right)}{\rho U^{2}}, \quad \text { Fr }=\frac{U}{\sqrt{g R_{0}}}, \\
\Delta=-\frac{\rho_{g} Q^{2}}{\pi^{2} R_{0}^{4} \rho U^{2} \ln \epsilon}, \quad a=\left[1-\frac{R_{b 0}^{2}}{R_{0}^{2}}\right]^{-2},
\end{gathered}
$$

where $\rho$ is the water density; $U$ is the constant velocity of the water flow at infinity; $p_{v}$ is the water vapor pressure at ambient temperature; $p_{\infty}$ and $p_{0}$ are pressures measured in the cross section of the cavity origin far away in the water flow and in the injected gas respectively; $\rho_{g}$ is the constant density of injected gas; $Q$ is the volumetric gas flow rate; $R_{b}, R_{b 0}$ are the radii of the hull at points $x$ and $x=0 ; \epsilon$ is a small parameter, the ratio of the maximum diameter of the system cavity-cavitator to its length.

In this papper we shall concentrate on the numerical solutions of equation (1) at different values of the Froude number Fr and parameter $k$. We shall calculate shapes and dimensions of ventilated cavities and analyse critical values of the injection rate.

\section{NUMERICAL PROCEDURE AND EXAMPLES OF THE VENTILATED CAVITY SHAPE CALCULATIONS}

To integrate the differential equation (1), the standard initial conditions at the cavity origine $x=0$

$$
R=1, \quad \frac{d R}{d x}=\beta
$$

and the 4-th order Runge-Kutta method were used.

The calculations showed that for coinciding directions of the gravity and the flow at infinity $(k=1)$, the cavity dimensions are limited at any gas injection rate. The situation is similar to the case of natural cavitation, when the solution of equation (1) has the following form (see [10]):

$$
R^{2}(x)=\frac{\sigma_{0} x^{2}}{2 \ln \epsilon}+\frac{k x^{3}}{3 \mathrm{Fr}^{2} \ln \epsilon}+2 \beta x+1
$$




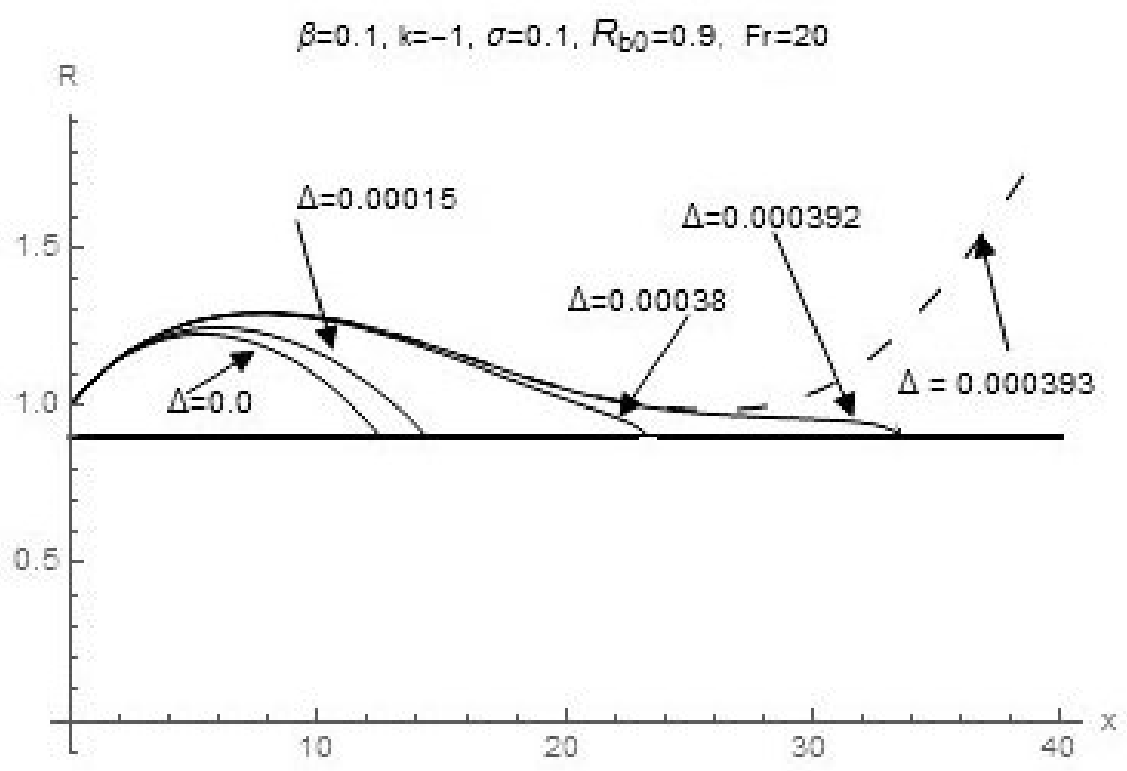

Fig. 1. Shapes of the ventilated cavities created by slender conical cavitator $(\beta=0.1)$ in the water flow directed upwards $(k=-1, \mathrm{Fr}=20)$ for different values of the gas flow rate.

The hull is cylindrical, $R_{b 0}=0.9, \sigma_{0}=0.1$

Since the value $\ln \epsilon$ is negative, the polynomial (2) can attain zero values at large enough values of $x$ at any Froude number. Thus, the cavity length and diameter are always limited.

Another behavior occurs at opposite directions of the gravity and velocity of the ambient flow $(k=-1)$. At some critical value of the Froude number the graph of the polynomial (2) touches the $x$ axes. Increasing the Froude number yields unlimited cavities, which cannot be realized according to the stability principle [11]. Corresponding critical Froude numbers were calculated in [10] for natural cavities and $R_{b 0}=0$. The results of the ventilated cavity shapes calculations are presented in Figs. 1 to 3 for $k=-1$, different cavitators $(\beta=0.1,0$, -0.1 ) and injection rates.

For the slender conical cavitator $\beta>0$, the dimensions of ventilated cavities increase with increasing the ventilation rate (see Fig. 1). At some critical value of ventilation parameter $(\Delta \approx 0.0003925)$ the cavity touches the cylindrical hull and becomes infinite. Since a small change in the flow parameters must cause small changes in the flow (according to the stability principle, see, e.g., [11]), the flow rate cannot exceed this critical value. An unrealistic infinite cavity is shown by the dashed line. Similar limited values of the ventilation rate occur on cylindrical hulls in liquid without gravity [6].

The length of the base cavities $(\beta \leq 0)$ decreases with increasing the ventilation rate (see Figs. 2 and 3). At some critical value of ventilation parameter the cavity touches the cylindrical hull and becomes infinite. Since a small change in the flow parameters must cause small changes in the flow (according to the stability principle, see, e.g., [11]), the flow rate cannot be smaller than this critical value. Unrealistic infinite cavities are shown in Figs. 2 and 3 by dashed lines. Similar limited values of the ventilation rate occur on cylindrical hulls in liquid without gravity [7]. 


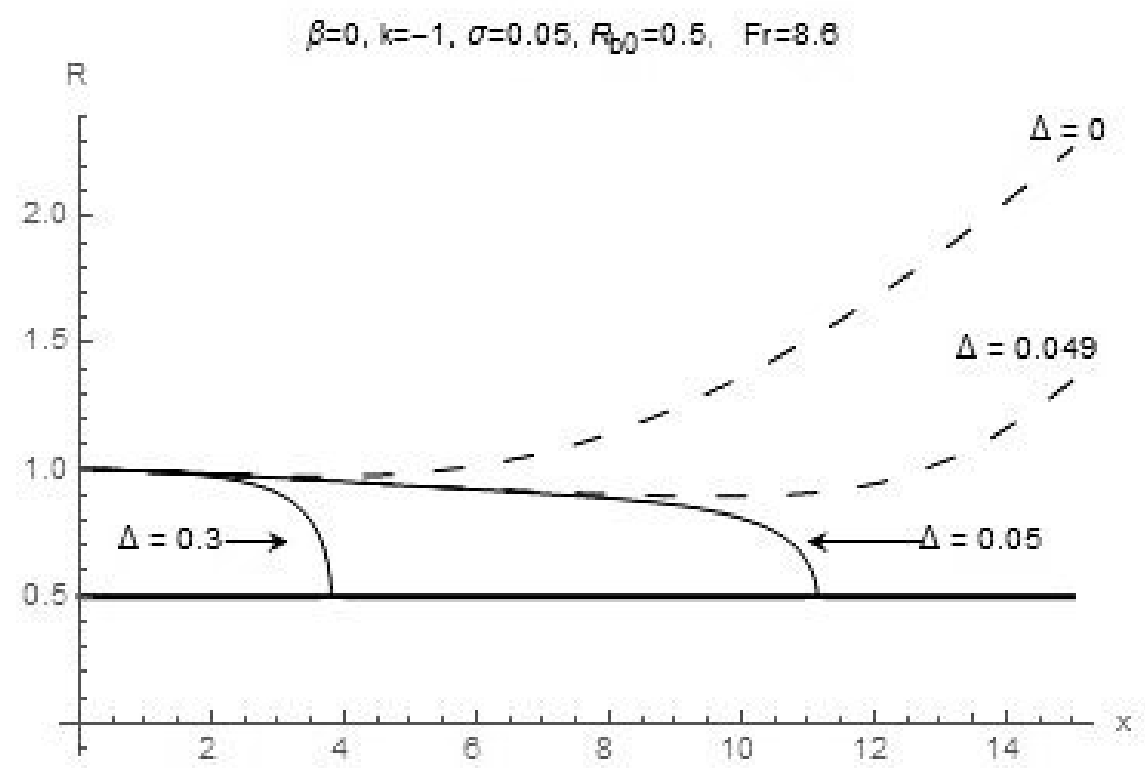

Fig. 2. Shapes of the base ventilated cavities, $\beta=0$ in the water flow directed upwards $(k=-1, \mathrm{Fr}=8.6)$ for different values of the gas flow rate. The hull is cylindrical, $R_{b 0}=0.5, \sigma_{0}=0.05$

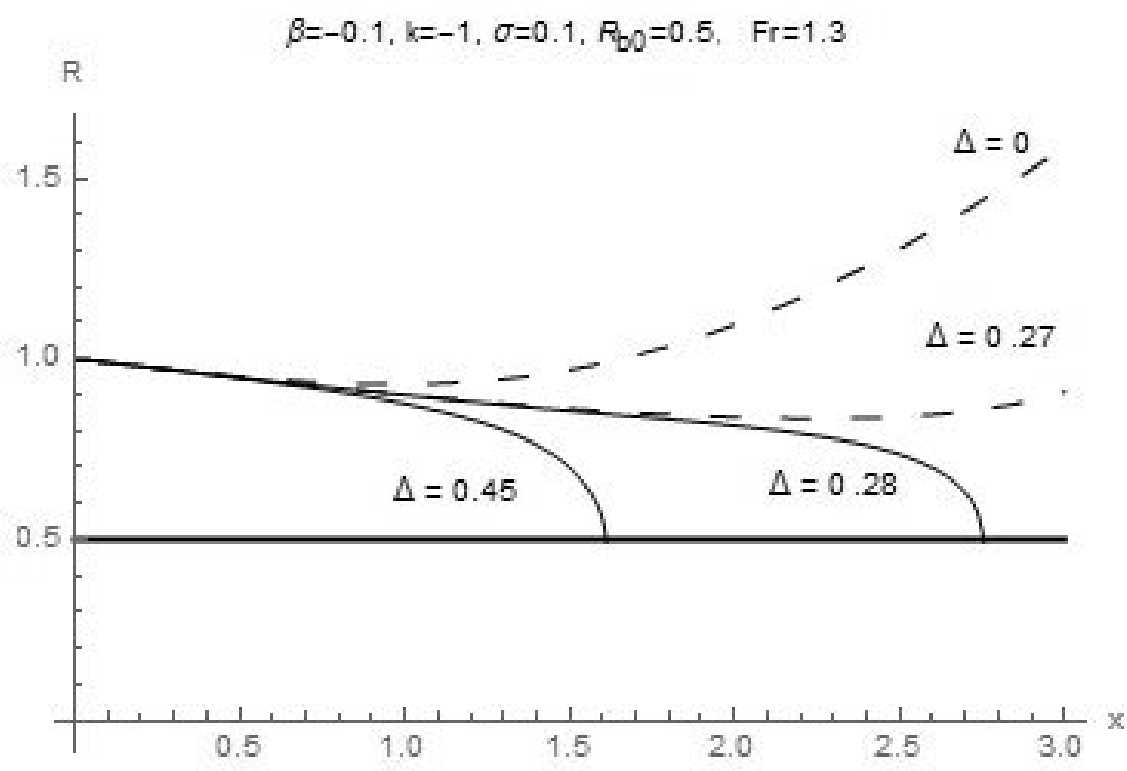

Fig. 3. Shapes of the base ventilated cavities, $\beta=-0.1$ in the water flow directed upwards $(k=-1, \mathrm{Fr}=1.3)$ for different values of the gas flow rate. The hull is cylindrical, $R_{b 0}=0.5, \sigma_{0}=0.1$ 


\section{DIMENSIONS OF THE VENTILATED CAVITIES, CREATED BY A SLEN- DER CONICAL CAVITATOR}

In the case of slender conical cavitator with $\beta=0.1$, the maximal cavity radius and the length of the ventilated cavities versus injection rate are presented in Figs. 4 to 7 . The dimensions of the ventilated cavity increase with the increasing of the ventilation rate at fixed values of the cavitation and Froude numbers and the radius of the cylindrical hull.

Figs. 4 and 5 show that the cavity dimensions decrease with the increasing of the Froude number in the water flow directed upwards $(k=-1)$ at fixed values of the cavitation number, flow rate and $R_{b 0}$. This behavior is typical for zero gas injection rates too (see equation (2)). With increasing $\Delta$ the influence of the Froude number increases. The critical values of the injection rates and corresponding cavity dimensions (see the tops of the curves shown in Figs. 4 and 5) also increase with the increasing Froude number. The increase of the radius of the cylindrical hull (parameter $R_{b 0}$ ) drastically diminishes the critical values of $\Delta$.

Figs. 6 and 7 show that the cavity dimensions increase with the increasing of the Froude number in the water flow directed downwards $(k=1)$ at fixed values of the cavitation number, flow rate and $R_{b 0}$. This behavior is typical for zero gas injection rates too (see equation (2)). The dimensions of the ventilated cavity increase with the increasing of the ventilation rate but remain limited. The increase of the radius of the cylindrical hull (parameter $R_{b 0}$ ) drastically increases the cavity dimensions.

\section{LENGTH OF THE BASE VENTILATED CAVITIES}

In the case of the base cavities $(\beta \leq 0)$ on the infinite cylindrical hull, the maximum radius of the cavity coincide with the radius of the cavitator in the section of the cavity origin $x=0$, i.e., $R_{\max }=1$. The lengths of the ventilated cavities versus injection rate are presented in Figs. 8 and 9 for $\beta=0$ and Fig. 10 and 11 for $\beta=-0.1$. It can be seen that the length diminishes with the increase of the ventilation rate for both directions of the water flow $(k=1$ and $k=-1)$. The increase of the radius of the cylindrical hull (parameter $R_{b 0}$ ) drastically diminishes the length of the cavity.

Figs. 8 and 10 show that the cavity dimensions decrease with the increasing of the Froude number in the water flow directed upwards $(k=-1)$ at fixed values of the cavitation number, flow rate and $R_{b 0}$. This behavior is typical for zero gas injection rates too (see equation (2)) and for the case of conical cavitator (see Fig. 5). At zero values of the gas flow rate, the cavities shown in Figs. 8 and 10 are closed. It means that there are no limitations for $\Delta$ for the parameters used to calculate these plots.

The Froude numbers of 8.6 and 1.3 used in Figs. 2 and 3 respectively were too small to have closed vapor cavities. In these cases only ventilated cavities can be realized at the ventilation rates grater than critical ones.

Figs. 9 and 11 show that the cavity dimensions increase with the increasing of the Froude number in the water flow directed downwards $(k=1)$ at fixed values of the cavitation number, flow rate and $R_{b 0}$. This behavior is typical for zero gas injection rates too (see equation (2)) and for the case of conical cavitator (see Fig. 7). At zero values of the gas flow rate the cavities are always closed in the water flow directed downwards $(k=1)$. It means that there are no limitations for the parameter $\Delta$. 


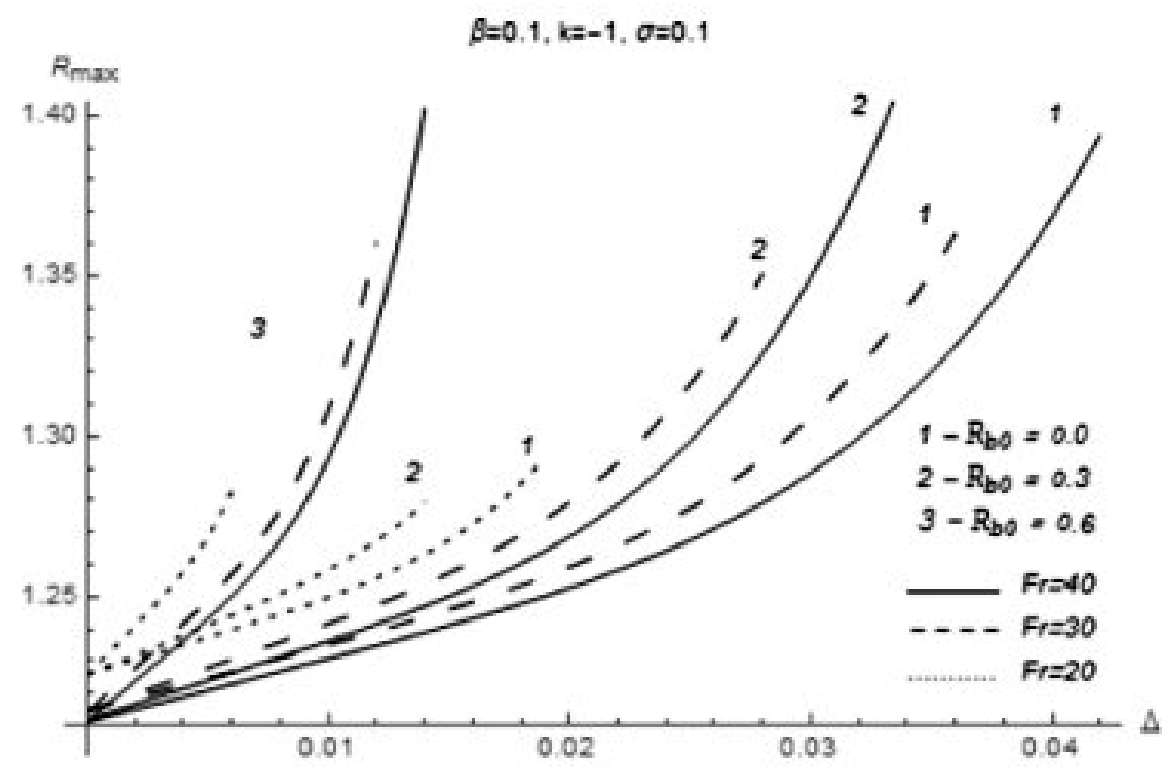

Fig. 4. Maximum radius of the ventilated cavity, created by slender conical cavitator with $\beta=0.1$ in the water flow directed upwards $(k=-1)$, versus injection rate at different Froude numbers and $R_{b 0}\left(\sigma_{0}=0.1\right)$

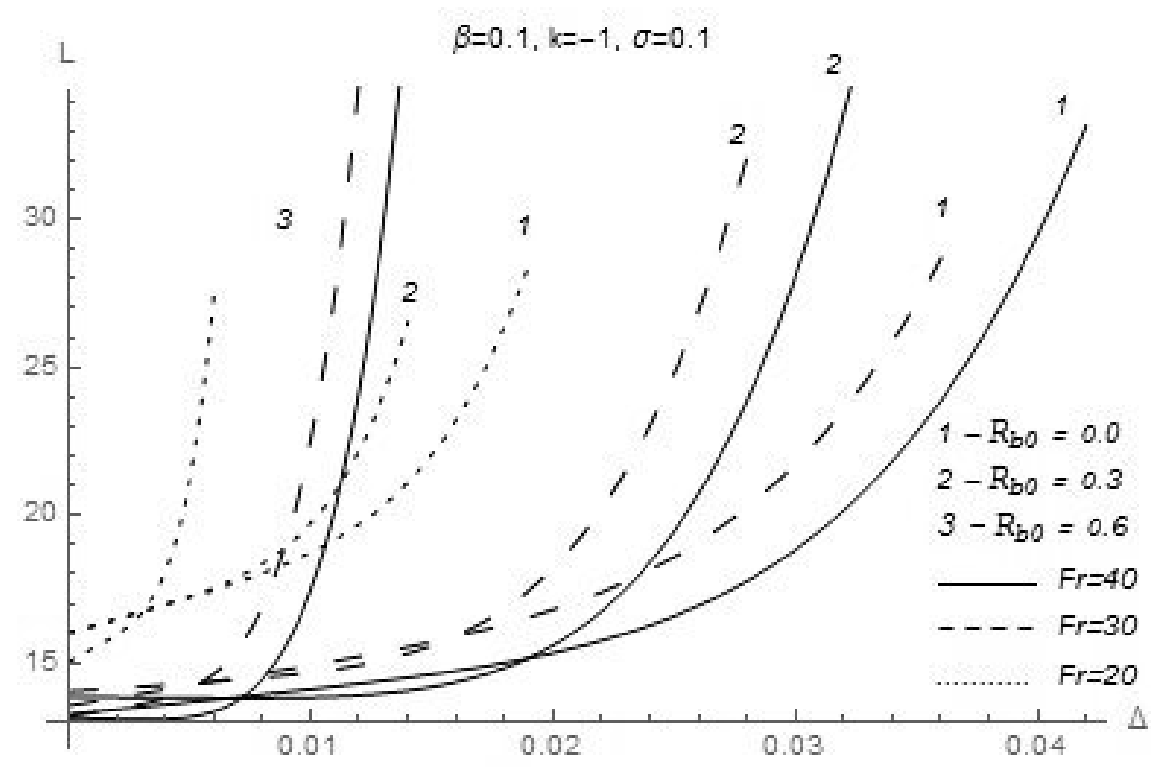

Fig. 5. Length of the ventilated cavity, created by slender conical cavitator with $\beta=0.1$ in the water flow directed upwards $(k=-1)$, versus injection rate at different Froude numbers and $R_{b 0}\left(\sigma_{0}=0.1\right)$ 


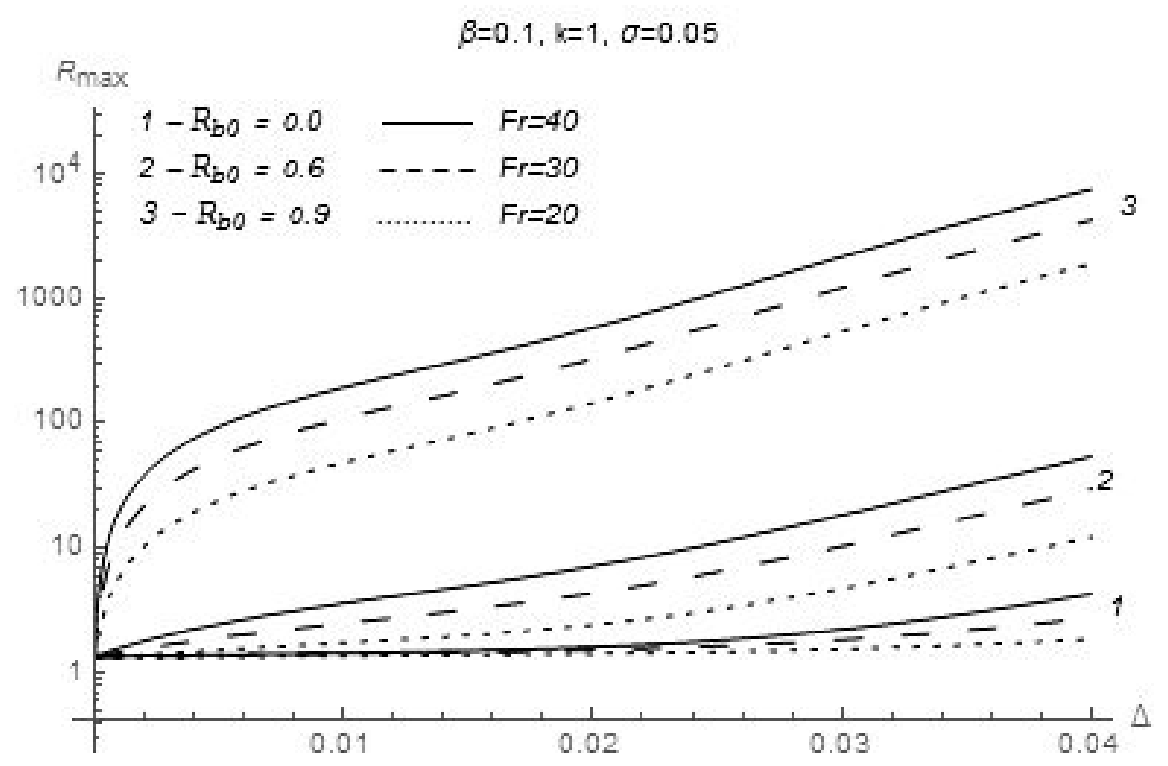

Fig. 6. Maximum radius of the ventilated cavity, created by slender conical cavitator with $\beta=0.1$ in the water flow directed downwards $(k=1)$, versus injection rate at different Froude numbers and $R_{b 0}\left(\sigma_{0}=0.05\right)$

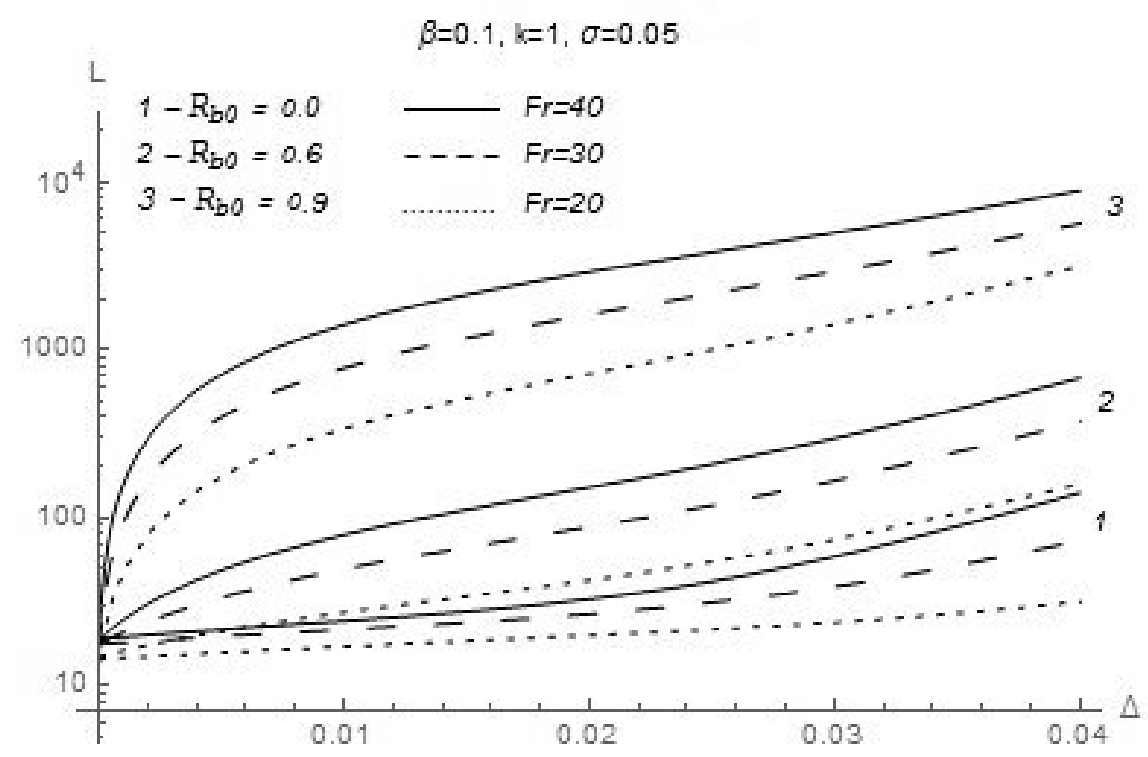

Fig. 7. Length of the ventilated cavity, created by slender conical cavitator with $\beta=0.1$ in the water flow directed downwards $(k=1)$, versus injection rate at different Froude numbers and $R_{b 0}\left(\sigma_{0}=0.05\right)$ 


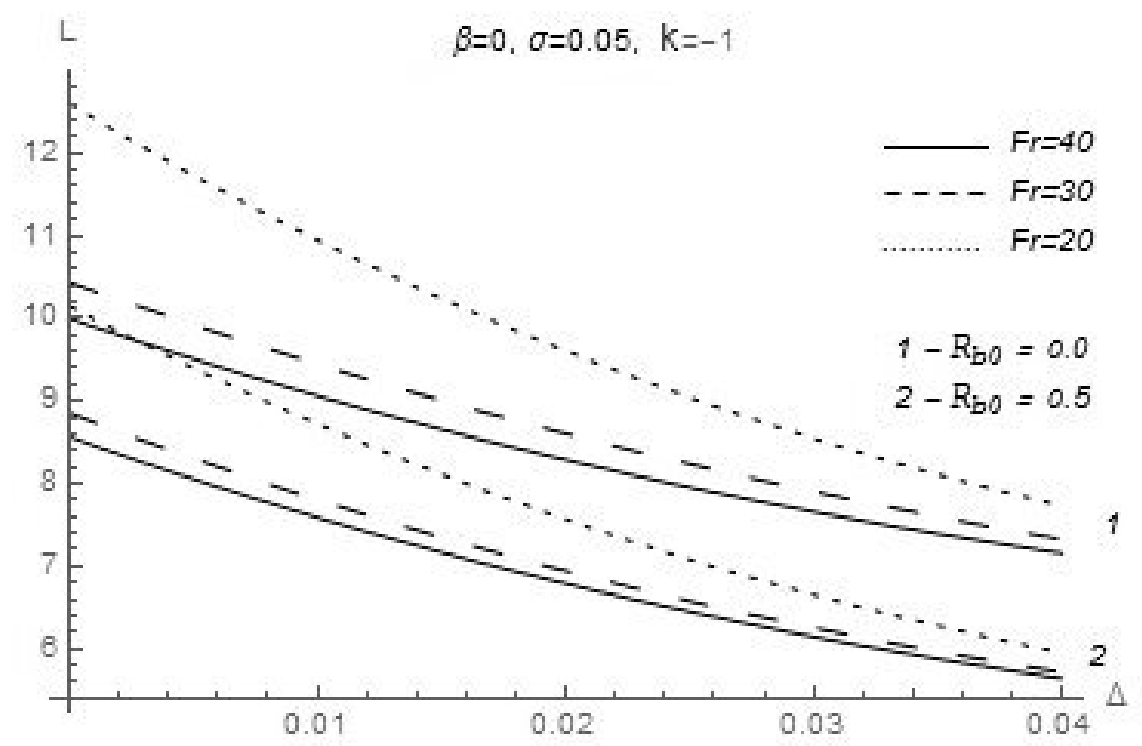

Fig. 8. Length of the base ventilated cavity for $\beta=0$ in the water flow directed upwards $(k=-1)$, versus injection rate at different Froude numbers and $R_{b 0}\left(\sigma_{0}=0.05\right)$

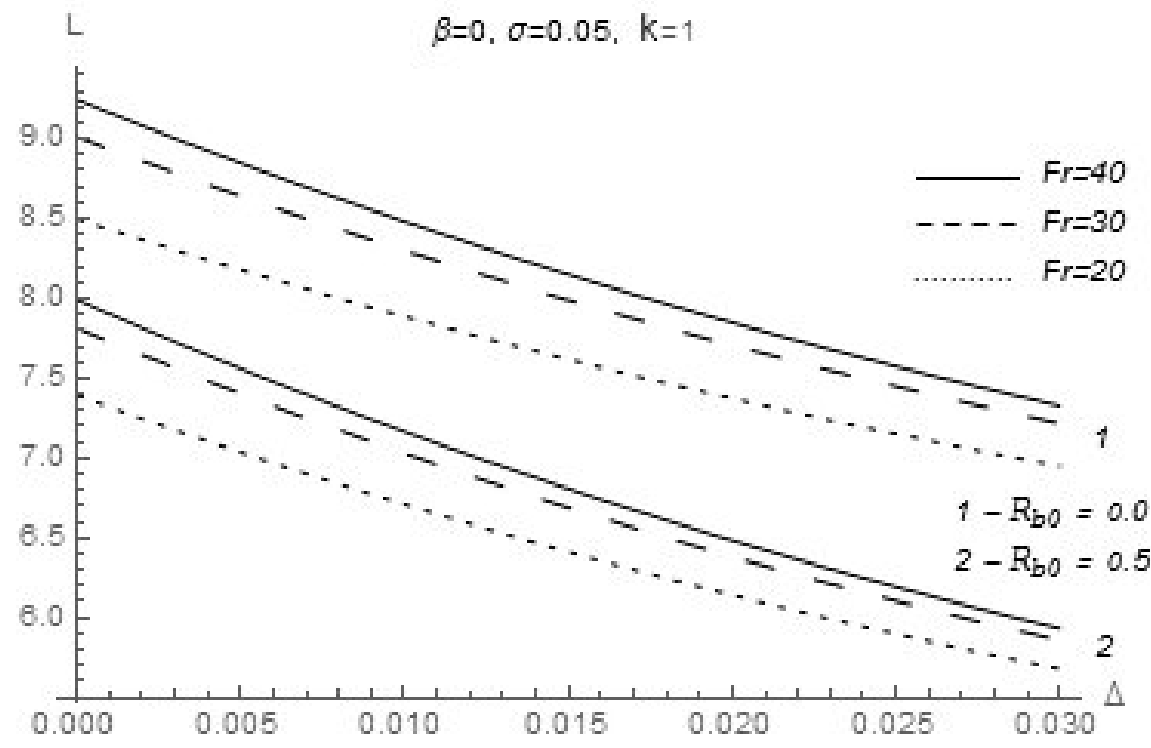

Fig. 9. Length of the base ventilated cavity for $\beta=0$ in the water flow directed downwards $(k=1)$, versus injection rate at different Froude numbers and $R_{b 0}\left(\sigma_{0}=0.05\right)$ 


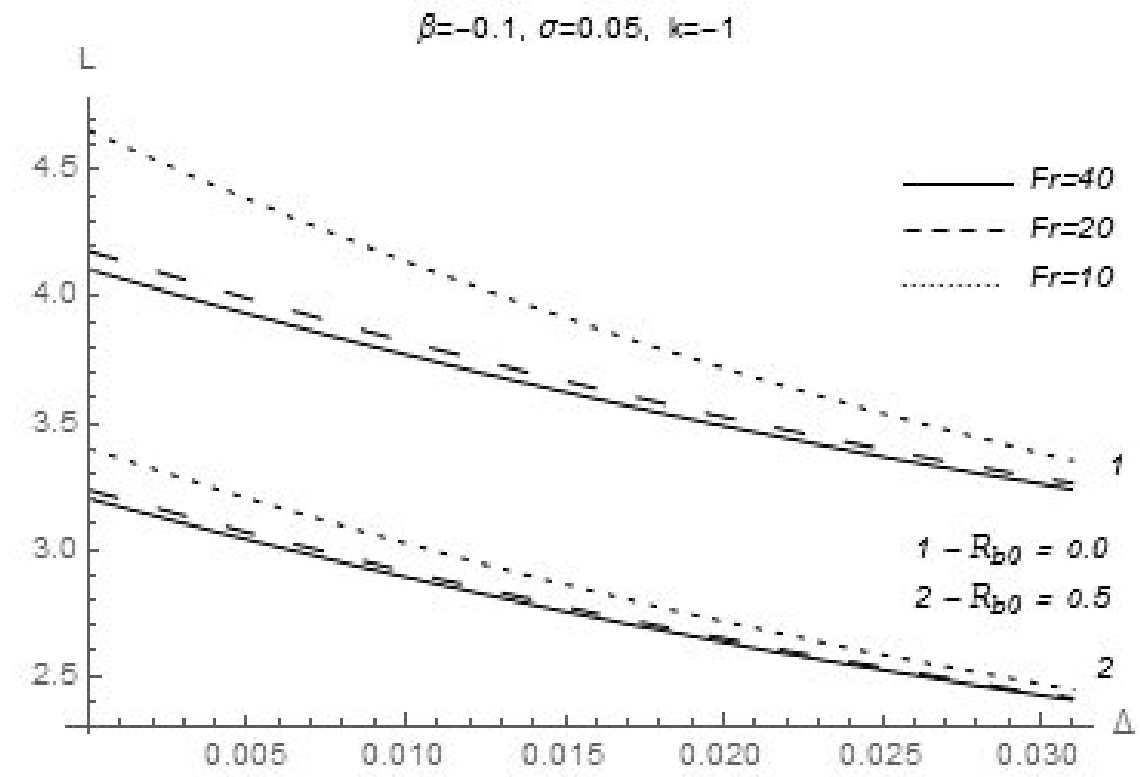

Fig. 10. Length of the base ventilated cavity for $\beta=-0.1$ in the water flow directed upwards $(k=-1)$, versus injection rate at different Froude numbers and $R_{b 0}\left(\sigma_{0}=0.05\right)$

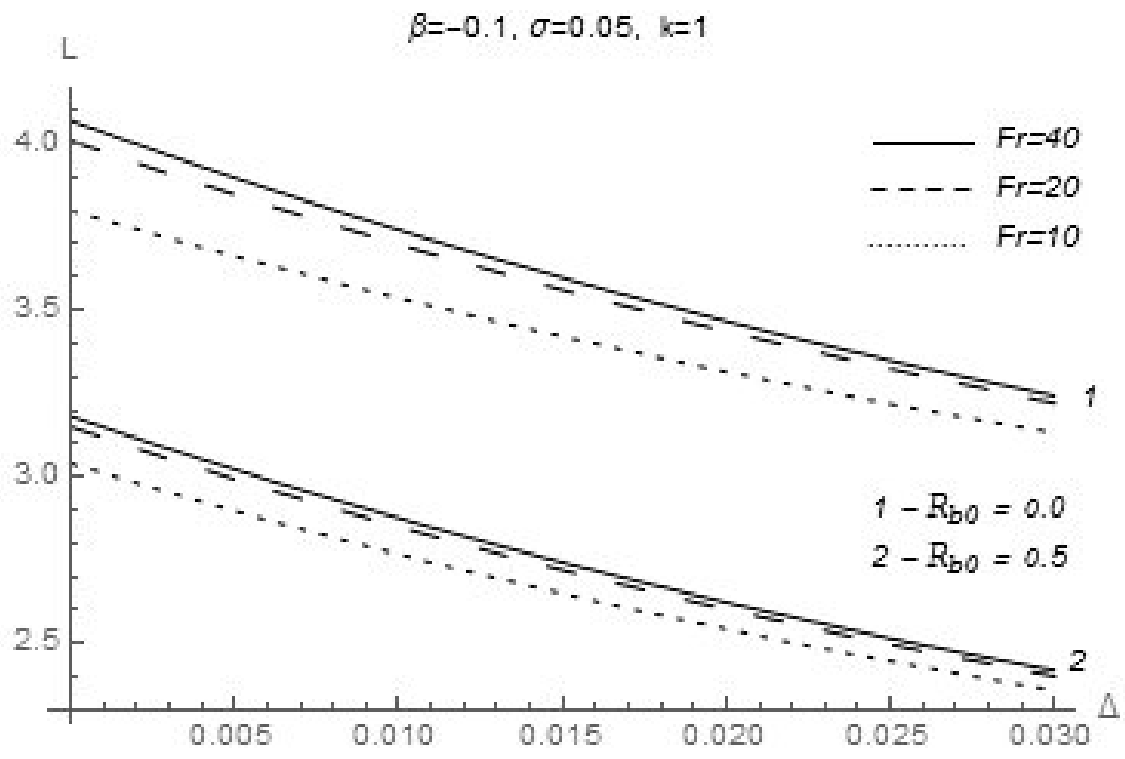

Fig. 11. Length of the base ventilated cavity for $\beta=-0.1$ in the water flow directed downwards $(k=1)$, versus injection rate at different Froude numbers and $R_{b 0}\left(\sigma_{0}=0.05\right)$ 


\section{CONCLUSIONS}

With the use of known differential equation of the first approximation, the shapes of the slender steady axisymmetric ventilated cavities were calculated for up- and downwards directions of the water flow for different values of the Froude number and the radius of the cylindrical hulls located inside the cavity. It was shown that ventilation increases the dimensions of the cavities created by conical cavitator and decreases the length of the base cavities. When the direction of the water flow at infinity is opposite to the direction of the gravity, the injection rate cannot exceed some critical value for conical cavitators and cannot be lower than some critical value for the base cavities.

Since the very simple one-dimensional model was used for the gas flow in the circular channel between the cavity surface and the hull, the results must be verified by experiments, applying CFD methods and using the viscous models for gas and water flows.

\section{REFERENCES}

[1] Логвинович Г. В. Гидродинамика течений со свободными границами. - Киев : Наукова думка, 1969. - С. 215.

[2] Savchenko Y. N. Perspectives of the supercavitation flow applications // International Conference on Superfast Marine Vehicles Moving Above, Under and in Water Surface (SuperFAST'2008). - St. Petersburg, Russia, 2008.

[3] Nesteruk I. G. Drag drop on high-speed supercavitating vehicles and supersonic submarines // Прикладна гідромеханіка. - 2015. - Т. 17(89), № 4. - С. 52-57.

[4] Vlasenko Y. D., Savchenko G. Y. Study of the parameters of a ventilated supercavity closed on a cylindrical body / / Supercavitation / Ed. by I. Nesteruk. - Springer, 2012.P. 201-214.

[5] Zhuravlev Y. F., Varyukhin A. V. Numerical simulation of interaction gas jets flowing into water cavity with its free surfaces simulation // International Conference on Superfast Marine Vehicles Moving Above, Under and in Water Surface (SuperFAST'2008).St. Petersburg, Russia, 2008.

[6] Манова 3. І., Нестерук І. Г., Шепетюк Б. Д. Оцінки впливу інтенсивної вентиляції на форму тонких осесиметричних каверн // Прикладна гідромеханіка. - 2011. - Т. 13(85), № 2. - C. 44-50.

[7] Нестерук І. Г., Шепетюк Б. Д. Особливості форми донних штучних осесиметричних каверн // Прикладна гідромеханіка. - 2011. - Т. 13(85), № 3. - С. 69-75.

[8] Нестерук I. Г., Шепетюк Б. Д. Форма штучних осесиметричних каверн при дота надкритичних значеннях інтенсивності піддуву // Прикладна гідромеханіка. 2012. - T. 14(86), № 2. - C. 53-60.

[9] Nesteruk I. Shape of slender axisymmetric ventilated supercavities // Journal of Computational Engineering. - 2014. - Vol. 2014. - P. 501590(1-18). 
[10] Nesteruk I. On the shape of a slender axisymmetric cavity in a ponderable liquid // Fluid Dynamics. - 1979. - Vol. 14, no. 6. - P. 923-927.

[11] Нестерук И. Г. Об ограничениях на параметры кавитационных течений // Прикладная математика и механика. - 1986. - Т. 50, № 4. - С. 584-588.

\section{REFERENCES}

[1] G. V. Logvinovich, Hydrodynamics of flows with free boundaries. Halsted Press, 1973.

[2] Y. N. Savchenko, "Perspectives of the supercavitation flow applications," in International Conference on Superfast Marine Vehicles Moving Above, Under and in Water Surface (SuperFAST'2008), (St. Petersburg, Russia), 2008.

[3] I. G. Nesteruk, "Drag drop on high-speed supercavitating vehicles and supersonic submarines," Applied Hydromechnics, vol. 17(89), no. 4, pp. 52-57, 2015.

[4] Y. D. Vlasenko and G. Y. Savchenko, "Study of the parameters of a ventilated supercavity closed on a cylindrical body," in Supercavitation (I. Nesteruk, ed.), pp. 201-214, Springer, 2012.

[5] Y. F. Zhuravlev and A. V. Varyukhin, "Numerical simulation of interaction gas jets flowing into water cavity with its free surfaces simulation," in International Conference on Superfast Marine Vehicles Moving Above, Under and in Water Surface (SuperFAST'2008), (St. Petersburg, Russia), 2008.

[6] Z. I. Manova, I. G. Nesteruk, and B. D. Shepetyuk, "Estimations of intensive ventilation influence on the slender axisymmetric cavity shape," Applied Hydromechnics, vol. 13(85), no. 2, pp. 44-50, 2011.

[7] I. G. Nesteruk and B. D. Shepetyuk, "Shape peculiarities of the base artificial axisymmetric cavities," Applied Hydromechnics, vol. 13(85), no. 3, pp. 69-75, 2011.

[8] I. G. Nesteruk and B. D. Shepetyuk, "Shape of artificial axisymmetric cavities at suband supercritical values of the ventilation rate," Applied Hydromechnics, vol. 14(86), no. 2, pp. 53-60, 2012.

[9] I. Nesteruk, "Shape of slender axisymmetric ventilated supercavities," Journal of Computational Engineering, vol. 2014, pp. 501590(1-18), 2014.

[10] I. Nesteruk, "On the shape of a slender axisymmetric cavity in a ponderable liquid," Fluid Dynamics, vol. 14, no. 6, pp. 923-927, 1979.

[11] I. Nesteruk, "The restrictions of the parameters of cavitational flow," PMM Journal of Applied Mathematics and Mechanics, vol. 50, no. 4, pp. 446-449, 1986. 
I. Г. Нестерук, Б. Д. Шепетюк

Форми стійких тонких осесиметричних вентильованих каверн у важкій рідині

Розраховані форми тонких усталених осесиметричних вентильованих каверн для висхідного та низхідного потоків води при різних значеннях числа Фруда і радіусів розташованих у каверні циліндричних корпусів. Показано, що вентиляція збільшує розміри каверн за конічним кавітатором і зменшує довжину донних каверн. Якщо напрямок потоку води на нескінченності протилежний до сили тяжіння, то інтенсивність піддуву не може перевищувати деяке критичне значення для конічних кавітаторів, а також не може бути меншою за деяке значення для донних каверн.

КЛЮЧОВІ СЛОВА: суперкавітація, вентильовані каверни, теорія тонкого тіла

\section{И. Г. Нестерук, Б. Д. Шепетюк}

Формы устойчивых тонких осесимметричных вентилируемых каверн в весомой жидкости

Рассчитаны формы тонких стационарных осесимметричных вентилируемых каверн для восходящего и нисходящего потоков воды при различных значениях числа Фруда и радиусов расположенных в каверне цилиндрических корпусов. Показано, что вентиляция увеличивает размеры каверн за коническим кавитатором и уменьшает длину донных каверн. Если направление потока воды на бесконечности противоположно силе тяжести, то интенсивность поддува не может превышать некоторое критическое значение для конических кавитаторов, а также не может быть меньше некоторого критического значения для донных каверн.

КЛЮЧЕВЫЕ СЛОВА: суперкавитация, вентилируемые каверны, теория тонкого тела 